\title{
Millennials Information-Seeking Behavior About Climate Change
}

\author{
Yanuar Luqman \\ \{yanuar.luqman@live.undip.ac.id\} \\ Universitas Diponegoro, Indonesia
}

\begin{abstract}
Climate change concern, especially the issue of climate change, is needed from millennials. Millennials is the next generation that can continue sustainable development. This study conducts to describe millennial information-seeking behaviour related climate change issue. The presence of technology and new media are driving millennial different communication patterns, especially about climate change. Information in the new media is so numerous and varied that it can provide alternative behavior in seeking information about climate change. Underpinning the cybernetic tradition, this research framework draws within the Expectancy-value theory approach and Computer-Mediated Communication. Using a survey research method of 545 of various students in Indonesia representing the millennial generation, this study aims to answer how millennial behaviour is in seeking information about climate change. This study's findings indicate that the discourse on millennial climate change is happening and very important to discuss because climate change is implemented as a result of human activities that are not environmentally friendly. Millennials tend to choose new media, especially social media, as a reference for data and information. These preferences should be presumed due to the more interactive and mass communication nature of social media compared to other media.
\end{abstract}

Keywords: Climate Change, Information-Seeking, Millennials

\section{Introduction}

The definition of climate change in this research refers to the United Nations Framework Convention on Climate Change/UNFCCC) as changes caused either directly or indirectly by human activities that change the composition of the global atmosphere and the variability of natural climate over comparable periods [2].

Climate change is a real-world situation that must be faced. The results of research conducted by the World Wildlife Fund (WWF) show that 33\% of the world's habitats are threatened by climate change, some plant and animal species are threatened with extinction. A report compiled by The Intergovernmental Panel on Climate Change (IPCC) in 2002 says that human activities cause global warming. The world usage of fossil fuel has led to an increased global temperature between 1.4 to 5.8 degrees Celsius [3].

Climate change is making the world face perhaps the most difficult survival challenges. Technological solutions have dominated the proposed interventions to overcome these challenges. Such solutions will never be sufficient to provide the necessary reductions in greenhouse gas emissions [4] without people's attitudes and lifestyle changes. Society can be the determining variable, if we can manage energy consumption wisely. Individuals' tendency 
to act pro-environmentally needs to be disseminated more widely to the public to create a more sustainable future [5][6][7][8].

Greta Thunberg, 16 years old from Sweden, has become the talk of global media for her actions on climate change, 'School Strike for Climate.' This action was done in front of the Swedish Parliament by demanding that world politicians pay more attention to the environment. On her next action, Thunberg attended the UN Climate Change Conference on 2-13 December 2019 by calling on the importance of world leaders' seriousness to think about the negative impacts of climate change [9]. Millennials are individuals who were born between 1982 and 1999. Sometimes referred to as Generation Y or Me Generation, individuals from this generation are influenced by the rise of the internet, this generation is usually said to have opinions, do not believe in institutions, are technologically savvy, fast learners, and involved themselves [10][11][12].

Based on data from the 2016 World Economic Forum [13], various global problems concern the millennial generation. The 2016 Global Shapers Annual Survey reveals that climate change is one of most significant concerns to millennials. Global warming is the top concern (45.2\%) followed by large-scale conflicts and wars, religious conflicts, and poverty. The millennial age group was identified as being more critical, information literate, and very close to technology.

This study aims to describe millennial behaviour in seeking information about climate change. There are several research results on similar themes. Gray et al. found no evidence suggesting that younger generations are more concerned with supporting political policies related to environmental issues than older generations [14]. Otto, S. et al. [8] provide a longitudinal analysis showing that children till young adult's attitudes and behaviors related to environmental issues show an inverted $U$ curve. Children from age 7-10 years old shows increased attitudes and behaviour related to environmental issues and were at the same level until age 14 years, and began to decline until age 18 years [15]. On another perspective, Chen \& Unsworth [16] found that participants with lower cognitive complexity tended to believe more in climate change when exposed to climate change information on their own. However, participants with higher cognitive complexity were more likely to believe in climate change when exposed to information that indicates denial of a fact accompanied with the true facts [16].

This research is the cybernetics tradition study that views communication problems as an effort to reduce uncertainty. The amount of information from a message is measured by how much information can overcome obscurities. Communication maintains an optimal balance between predictability and uncertainty [17].

This research is associated with environmental communication. The central concept of environmental communication is communication approaches, principles, strategies, and techniques of environmental management and protection. Environmental communication is a deliberate exchange of information, both in the form of knowledge and environmental policies [18]. Emily Plec [19] uses the phrase inter natural communication, denoting interactions between natural communities and social groups that include participants from what was initially described as different classifications of nature. The way of communicating influences world perception of nature, how to define and act on relationships with nature. Human discourse about nature reflects, builds, produces, and naturalism human attitudes and practices towards the environment.

The basis of this research is the Expectancy-value theory (EVT) [19], which suggests that "people direct themselves to the world according to their expectations (beliefs) and evaluations." The essence of EVT is two variables-valence and weights. Ideally, in the context 
of this research, whether or not the climate change issue will be considered supportive, it will have a positive valence and vice versa. In terms of the weight of climate change issues, credibility is the primary key. If the information related to climate change is correct, the more significant the impact on the belief system.

The millennial generation cannot be separated from the presence of information technology, especially the internet. The advantage of new technology, which in this case is the internet, lies in the optimal visualization of messages. The internet is the primary choice for millennials because millennials are visual learners [20]. The advent of the internet and the development of social media as well as Computer-Mediated Communication (CMC) have created additional forms of reality. This reality is "new media" [19].

CMC provides many conveniences for humans, but Bromme et al. [21] revealed that this media has weaknesses. The first potential weakness is the different interpretations between actors in interpreting messages, interaction structures, such as indirect relationships. The learning process through internet intermediaries also requires a social structure to ensure the continuity of the information dissemination process. Thurlow et al. [22] added that "absence" is a CMC weakness, which triggers a low social presence.

\section{Methodology}

This research is quantitative and is described as descriptively. This study's population was students in Indonesia (diploma and bachelor's degree) who were included in the millennial generation, originating from the regions of the islands of Java, Sumatra, Kalimantan, BaliNusa Tenggara, and Sulawesi-Maluku-Papua.

The survey was conducted using the online questionnaire and employed nonprobability sampling method with a sample size of 545 participants. In the age range of 17-25 years, the proportion of participants study fields was the most in the socio-humanities (67.25), while science and technology were $32.8 \%$.

The survey questions are an adaptation of previous surveys conducted by Leiserowitz et al. [23] and Metag et al. [24]. To measure millennials' media usage and preferences in seeking climate change information, participants were asked how often they discussed the issues with friends and family, as well as how often they get climate change information from different types of media, namely television, radio, paper-based media, films, and the internet. Belief about climate change was captured by several items, like acknowledgement whether climate change is happening, how important they perceived the issue as well as how they conceptualize climate change causes.

\section{Results and Discussion}

In this section, the survey results will be presented, divided into two parts, namely on communication patterns (discussion, use of media consisting of $\mathrm{TV}$, radio, paper-based media, films, and the internet).

First, millennials discuss climate change issues with various aspects with their closest people (family or friends). The data in Figure 1 shows that among millennials, climate change is discussed with family and friends in the rare category $(35.6 \%)$ to the frequent category 
(29.9\%). This finding shows that millennials do not talk much about climate change issues with their closest people (family and friends).

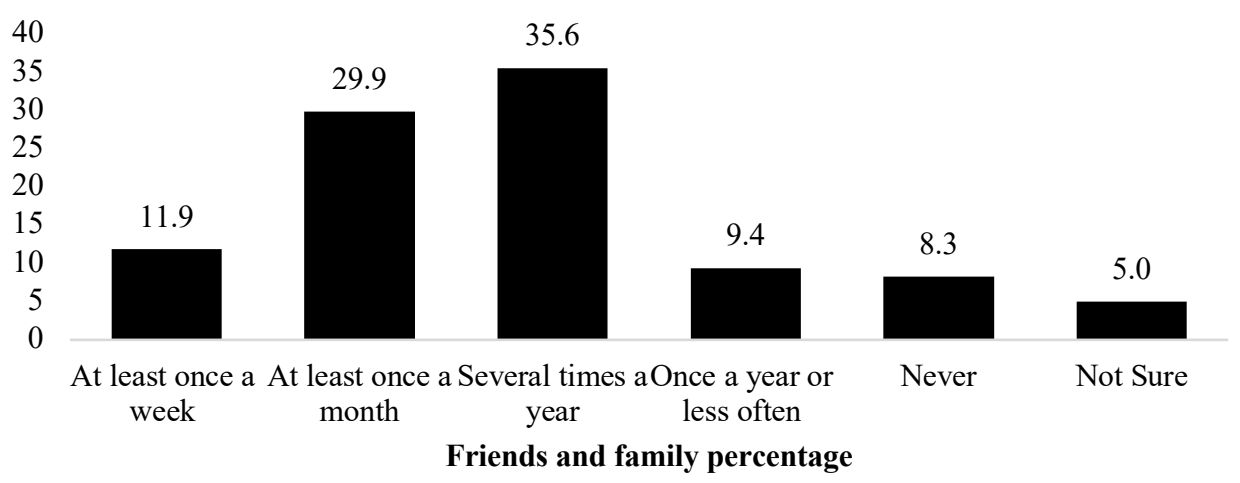

Fig. 1. Millennials frequency of climate change discussions with family and friends.

Second, millennials tend not to use conventional media (TV, radio, paper-based media) much in seeking data and information about climate change. As in Figure 2,3 and 4, millennials stated that TV $(37.8 \%)$, radio $(31.9 \%)$ as well as paper-based media $(29.9 \%)$ are sources they rarely accessed.

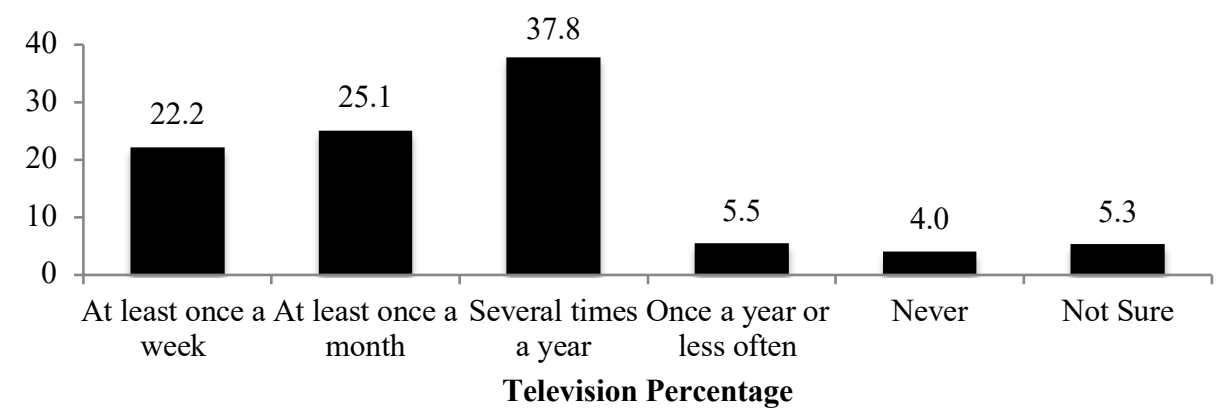

Fig. 2. Millennials access to climate change issues in television (TV).

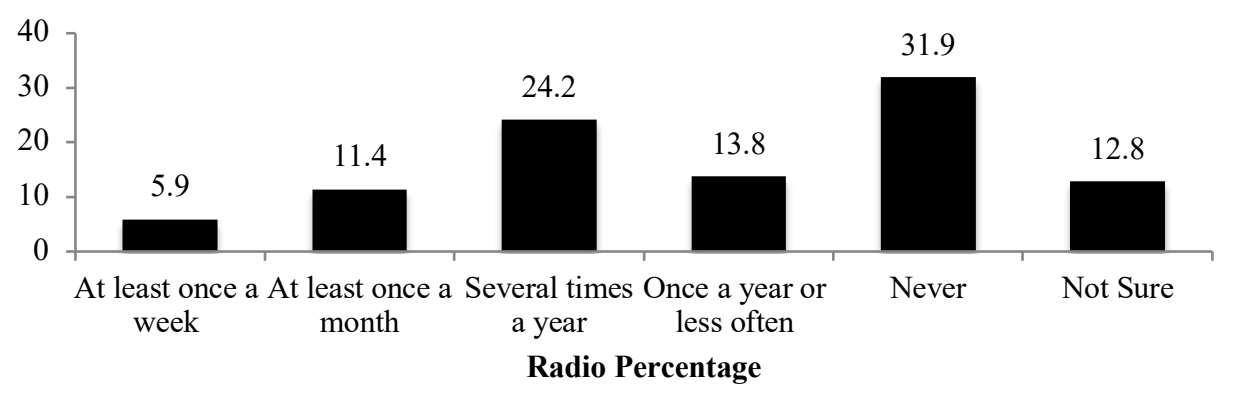

Fig. 3. Millennials access to climate change issues in radio. 


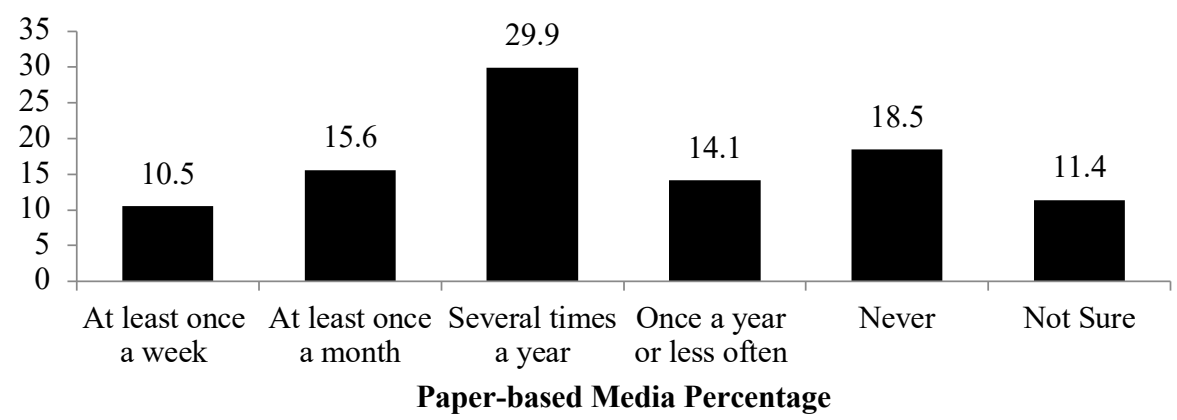

Fig. 4. Millennials access to climate change issues in newspapers/magazines (paper-based media).

It may be said that millennials do not make conventional (non-internet) media, the primary source of data and information on climate change discourse.

Third, in contrast to conventional media as a source of data and information on climate change, the internet seems to be the dominant media used by millennials as a reference. As in Figure 5 it shows that government websites tend to be used very frequently with a range of $26.6-18.9 \%$. In the same way, millennials stated that they frequently use online news as a reference in the range of $34.1-30.1 \%$ (Figure 6). The most dominant source of referrals is social media, at $43.3 \%$ (Figure 7 ).

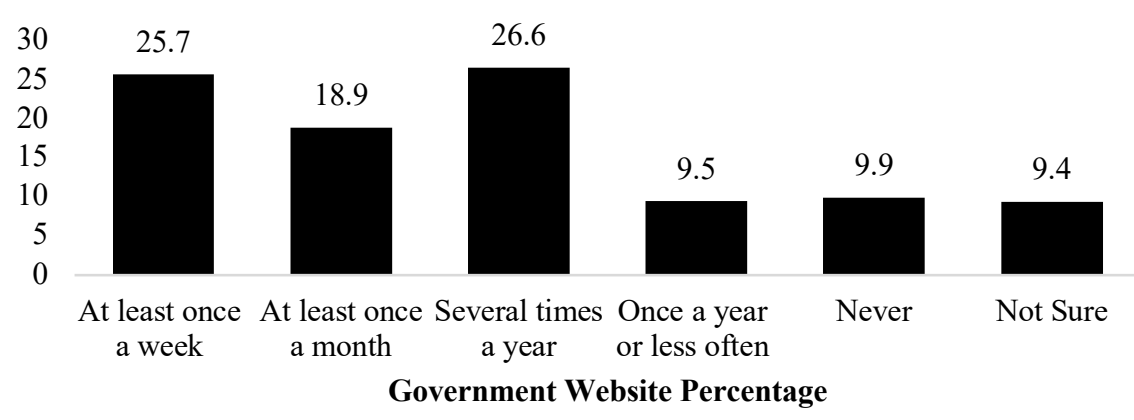

Fig. 5. Millennials access to climate change issues on internet media government website.

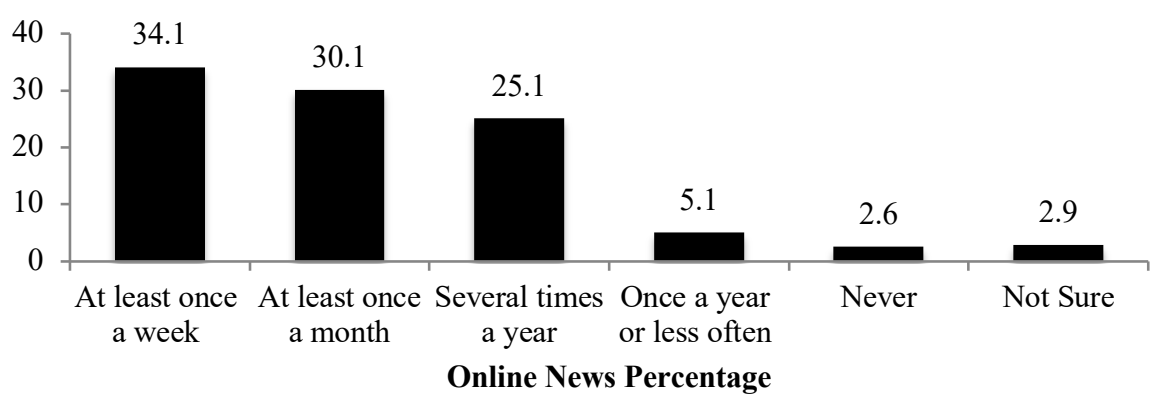

Fig. 6. Millennials access to climate change issues on internet media: online news. 


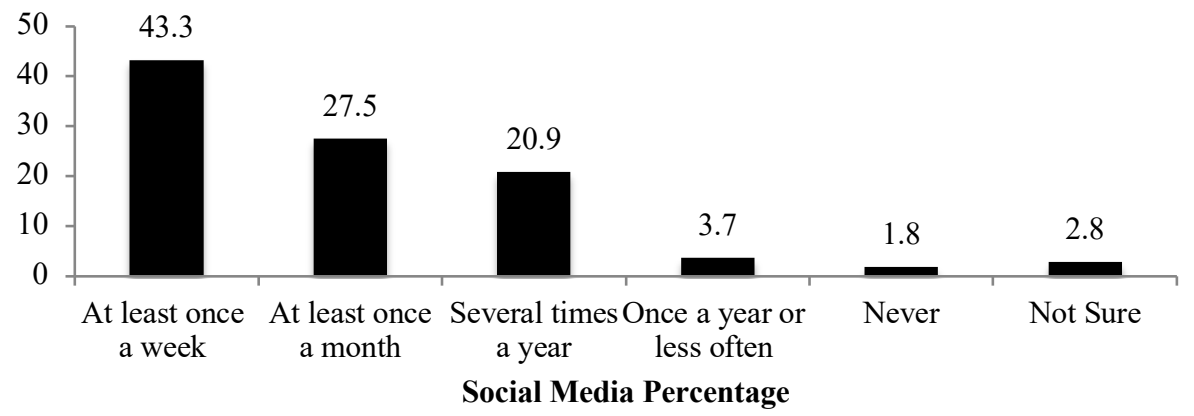

Fig. 7. Millennials access to climate change issues on internet media social media.

It can be concluded that millennials have made new media (internet) as the primary source of data and information on climate change discourse, especially social media.

Fourth, there are at least seven documentaries and fiction films with the theme of climate change. These films are Beasts of the Southern Wild (2012), Waterworld (1995), Geostorm (2017), Downsizing (2017), An Inconvenient Sequel: Truth To Power, The Day After Tomorrow (2004), and Before the Flood (2016) [25]. Figure 8 shows how millennials are associated with this kind of theme in the film. As can be seen, millennials rarely (41.1\%) observe climate change issues through film.

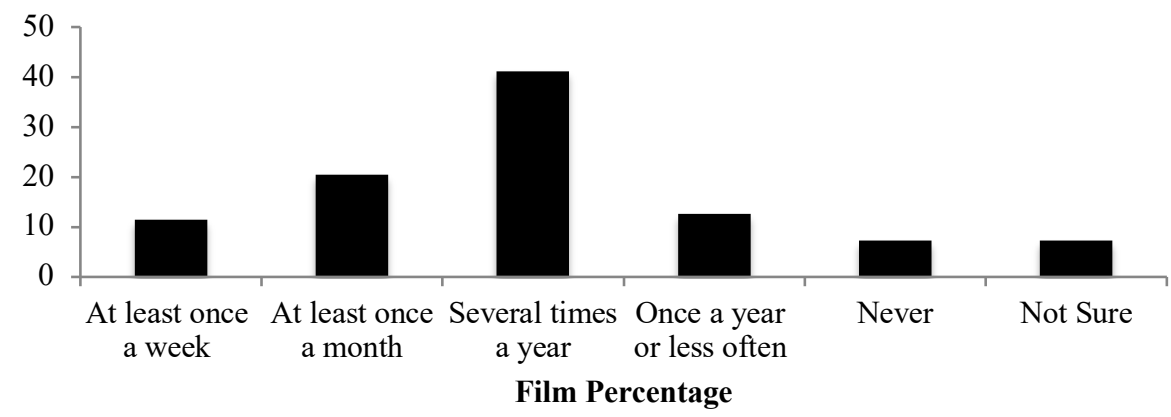

Fig. 8. Millennials observing climate change in film.

There are two allegations regarding the findings of millennials seeking behavior through film mentioned before. The first possibility is that these films are not well-accessed by millennials. Second, it is possible that millennials do watch these films without realizing that these films depict the issue of climate change wrapped in the documentary genre or the science fiction genre.

Millennials are very aware of climate change. Most of them $(97.6 \%)$ think that the warming associated with climate change is happening, as it shown in Figure 5 below. 


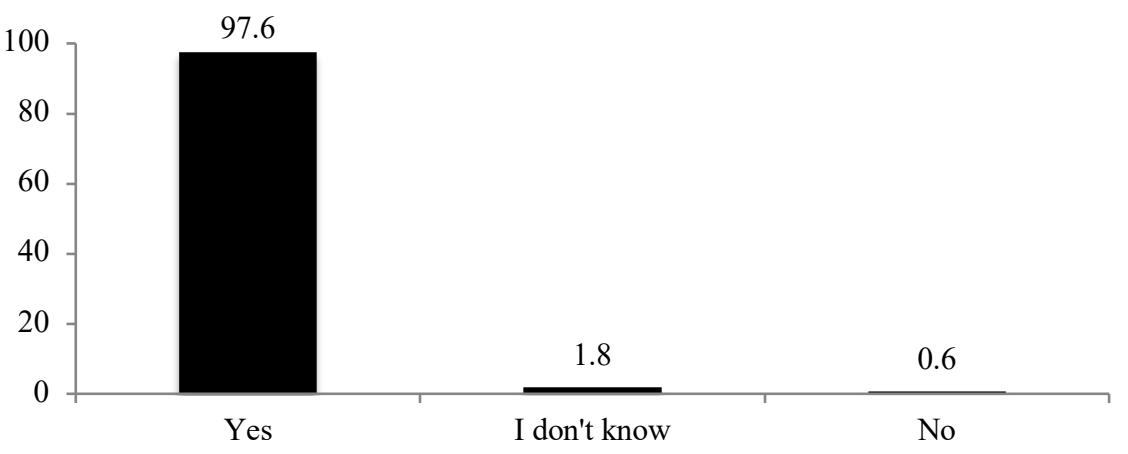

Fig. 9. Millennials opinion on climate change.

Following is the data that shows that millennials think that talking about climate change is very important and important, as shown in Figure 9. This data shows that millennials are aware of the urgency of discussing climate change because it relates to environmental conditions and human survival concerns.

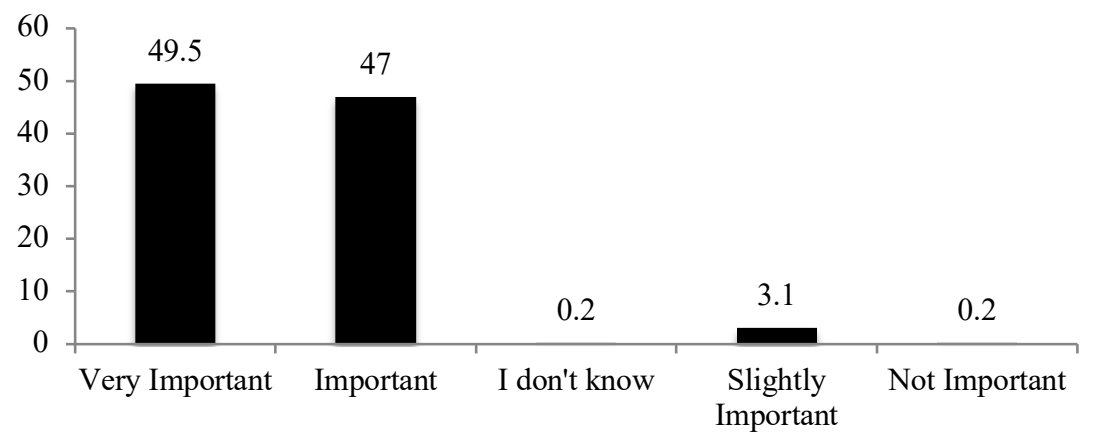

Fig. 10. Millennial opinion on the importance of talking about climate change.

How millennials think about the importance of talking about climate change can be linked to millennials opinion on the causes of climate change. The data in Figure 10 shows that most millennials state that human activities are the most significant contributor to climate change $(87.5 \%)$. It is essential because humans are the main actors of climate change, and this can be anticipated by talking about it massively and continuously.

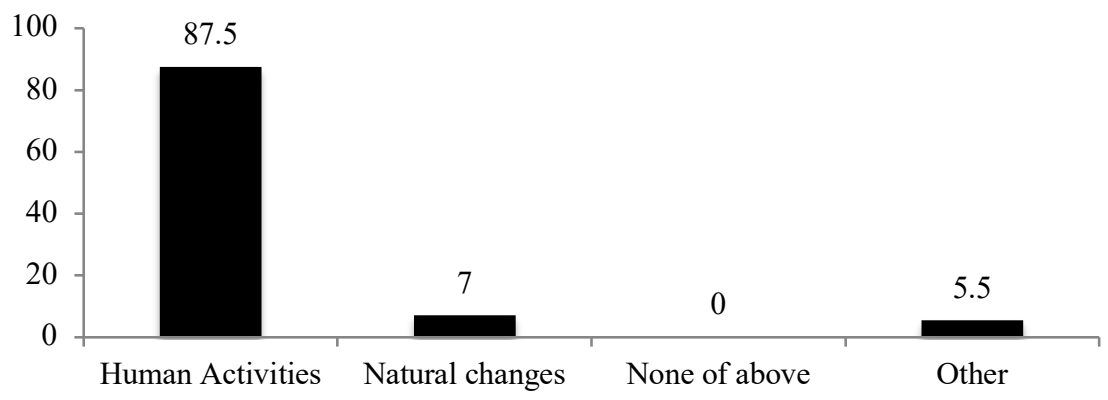

Fig. 11. Millennials opinion on the causes of climate change. 
On the perspective of EVT theory, the findings above indicate the proposed concept whether or not the issue of climate change will be considered supportive, it will have a positive valence and vice versa. Millennial considering the credibility of data and information sources (social media). If the information related to climate change is correct, the more significant the impact on the belief system means they believe that climate change is real and happening.

Align with $\mathrm{CMC}$, new media (social media) is the top choice for millennials because millennials are visual learners. New media has advantages in the visual aspect. However, it should be noted that new media has the disadvantage of a low social presence.

\section{Conclusion}

To conclude this study, it may be said millennials think that climate change is not only happening but also critical to discuss because of the fact that climate change is being understood as the result of human activities that are not pro-environment. Millennials have a tendency to choose new media, especially social media, as data and information sources. These preferences should be presumed due to social media's nature, which is more interactive and mass self-communication compared to other online media such as government website or online news. In addition this study has several limitations, further information about what kind of information millennials read, watch or heard from media would strengthened the conclusion.

\section{References}

[1] F. Edition, "Diagnostic and statistical manual of mental disorders," Am Psychiatr. Assoc, 2013.

[2] "http://ditjenppi.menlhk.go.id/kcpi/ index.php/info-iklim/perubahan-iklim.”.

[3] "[2] (https://www.wwf.or.id/tentang_wwf/ upaya_kami/iklim_dan_energi/solusikami/kampanye/powerswitch/mgp_ps/pist/).”.

[4] [IEA] International Energy Agency, World Energy Outlook 2013. Paris: OECD/IEA.

[5] R. Gifford, "The dragons of inaction: psychological barriers that limit climate change mitigation and adaptation," Am. Psychol., 2011.

[6] (2013). Liefländer, A.K., Fröhlich, G., Bogner, F.X., Schultz, P.W., "Promoting connectedness with nature through environmental education," Environ. Educ. Res., 2013.

[7] E. Van der Werff, L. Steg, and K. Keizer, "It is a moral issue: The relationship between environmental self-identity, obligation-based intrinsic motivation and pro-environmental behaviour," Glob. Environ. Chang., vol. 23, no. 5, pp. 1258-1265, 2013.

[8] S. Otto, F. G. Kaiser, and O. Arnold, "The critical challenge of climate change for psychology," Eur. Psychol., 2014.

[9] "Kisah Greta Thunberg, remaja yang menantang pemimpin dunia di konferensi perubahan iklim COP25." [Online]. Available: https://www.bbc.com/indonesia/majalah-50697434 .

[10] K. W. Smolka and C. D. Sutton, "Generational differences: revisiting generational work values for the next millennium," J Org Behav, vol. 23, pp. 363-382, 2002.

[11] J. M. Twenge, S. M. Campbell, B. J. Hoffman, and C. E. Lance, "Generational differences in work values: Leisure and extrinsic values increasing, social and intrinsic values decreasing," $J$. Manage., vol. 36, no. 5, pp. 1117-1142, 2010.

[12] C. Elam, T. Stratton, and D. D. Gibson, "Welcoming a new generation to college: The millennial students.," J. Coll. Admiss., vol. 195, pp. 20-25, 2007.

[13] "10 Masalah Utama Dunia Menurut Generasi Millenial." .

[14] S. G. Gray, K. T. Raimi, R. Wilson, and J. Árvai, "Will Millennials save the world? The effect 
of age and generational differences on environmental concern,” J. Environ. Manage., vol. 242, pp. 394-402, 2019.

[15] S. Otto, G. W. Evans, M. J. Moon, and F. G. Kaiser, "The development of children's environmental attitude and behavior," Glob. Environ. Chang., vol. 58, p. 101947, 2019.

[16] L. Chen and K. Unsworth, "Cognitive complexity increases climate change belief," J. Environ. Psychol., vol. 65, p. 101316, 2019.

[17] E. A. Griffin, "A first look at communication theory/Em Griffin.” New York: McGraw-Hill, 2012.

[18] A. G. Flor, Komunikasi Lingkungan: Penanganan Kasus-Kasus Lingkungan Melalui Strategi Komunikasi. Prenada Media, 2018.

[19] S. W. Littlejohn and K. A. Foss, Theories of human communication. Waveland press, 2010.

[20] S. G. Moreton, A. Arena, M. J. Hornsey, C. R. Crimston, and N. Tiliopoulos, "Elevating nature: Moral elevation increases feelings of connectedness to nature," J. Environ. Psychol., vol. 65, p. 101332, 2019.

[21] R. Bromme, F. W. Hesse, and H. Spada, Barriers and biases in computer-mediated knowledge communication: and how they may be overcome, vol. 5. Springer Science \& Business Media, 2006.

[22] C. Thurlow, L. Lengel, and A. Tomic, Computer mediated communication. Sage, 2004.

[23] A. Leiserowitz et al., "Climate change in the American mind: April 2020," 2020.

[24] J. Metag, T. Füchslin, and M. S. Schäfer, "Global warming's five Germanys: A typology of Germans' views on climate change and patterns of media use and information," Public Underst. Sci., vol. 26, no. 4, pp. 434-451, 2017. 